\title{
SITE SELECTION ASSESSMENT OF VACANT CAMPUS SPACE TRANSFORMING INTO DAILY CARE CENTERS FOR THE AGED
}

\author{
Yi-Kai JUAN${ }^{*}$, Yi-Chu HSU, Yen-Ping CHANG \\ Department of Architecture, National Taiwan University of Science and Technology \#43, Sec. 4, \\ Keelung Rd. Taipei, 106, Taiwan, R.O.C.
}

Received 03 May 2019; accepted 07 August 2020

\begin{abstract}
Taiwan is facing the dual severe social problems of an aging population coupled with a low birth rate. Aging has given rise to an urgent need for future long-term care and daytime care, while the low birth rate has led to a large number of vacant classrooms on campus. The government is actively developing the policy of reusing idle campuses as daily care centers for the aged. However, the implementation of this policy lacks a set of complete evaluation mechanisms. The purpose of this study was to propose a three-stage site selection assessment model to construct site selection assessment indicators, construct indicator weights using the analytic hierarchical process (AHP), and rank the campuses most suitable for transformation into daily care centers for the aged according to the Technique for Order Preference by Similarity to Ideal Solution (TOPSIS) method. The results showed that the convenience of family members' transportation, access to medical treatment, service life of school buildings, barrier-free spaces, and ventilation condition are all key factors regarding the future transformation of vacant campus spaces into daily care centers. The assessment model could provide a reference to accelerate the decision-making benefits regarding the sustainable reuse of idle campus spaces.
\end{abstract}

Keywords: site selection, vacant campus space, daily care centers for the aged, sustainable reuse, AHP, TOPSIS.

\section{Introduction}

According to the World Health Organization's definition, a country enters an aging society when its population over 65 years of age exceeds $7 \%$ of the total population; if the ratio of elderly is over $14 \%$, then the country will become an aged society (World Health Organization [WHO], 2001). Taiwan entered an aging society in 1993 and officially became an aged society at the end of March, 2018 (Department of Statistics, Ministry of the Interior [DSMI], 2018). When the aging society appears, it is bound to generate future demand for long-term care. Taking Taipei City as an example, the number of people receiving long-term care in 2016 was about 120,000; however, currently there are only 15 daily care centers for the aged in Taipei City, and only 510 people can be accommodated. The urgency of the current demand for daily care centers for the aged is apparent. In order to increase the supply of long-term care services, the government has presented a new system of long-term care service subsidies and units to facilitate the establishment of daily care centers for the aged since 2018 (The Executive Yuan, 2018).
In addition to the problem of aging, a low birth rate is another phenomenon accompanying the development of a modern society. According to the DSMI, Taiwan's total birth rate was only 1.17 children per couple in 2016 (Department of Statistics, Ministry of the Interior, 2016), which represents the phenomenon of ultra-low fertility (lower than 1.3) (Kohler et al., 2002). Due to the declining birth rate in Taiwan, the number of secondary and elementary school students is decreasing year by year; these schools are everywhere facing class reductions, mergers, and even closures, resulting in a large number of vacant classrooms and spaces.

The urgent need for long-term care due to aging and the problem of vacant campus spaces due to the low birth rate are serious problems faced by the Taiwan government. Due to greater urbanization coupled with medical facilities, it is more difficult for densely populated urban centers to be used as daily care centers for the aged. However, nearly $70 \%$ of the elderly in Taiwan hope to spend their twilight years in familiar surroundings (Department of Social Welfare, Taipei City Government, 2016). Secondary and elementary school campuses present a possible

*Corresponding author. E-mail: rik@mail.ntust.edu.tw

Copyright $\odot 2020$ The Author(s). Published by Vilnius Gediminas Technical University

This is an Open Access article distributed under the terms of the Creative Commons Attribution License (https://creativecommons.org/licenses/by/4.0/), which permits unrestricted use, distribution, and reproduction in any medium, provided the original author and source are credited. 
solution for setting up daily care centers for the aged due to their neighborhood accessibility. In order to give full play to the efficacy and value of urban space, the government has begun to consider and evaluate the feasibility of converting vacant campus spaces in the cities into daily care centers for the aged, and has begun to formulate relevant policies to actively promote the reuse of vacant campus spaces.

The aim of this study was to establish a systematic assessment method for the successful conversion of idle school buildings into daily care centers for the aged. This study was carried out in three stages. First, this study collected data and documents of cases regarding the combination of campus and daily care centers for the aged at home and abroad to understand the needs of the elderly, and summarized specific site selection evaluation indicators. Secondly, through the Analytic Hierarchical Process (AHP), experts were invited to answer a questionnaire and the weights of the site selection indicators were calculated. Finally, a case study of a campus with more vacant space released by the Ministry of Education was taken as an example, and the Technique for Order Preference by Similarity to Ideal Solution (TOPSIS) was used to rank the most suitable campuses to be converted into daily care centers for the aged. The results could provide a reference for the conversion of vacant campus spaces into different buildings for reuse.

\section{Trend of aging and low birth rate}

\subsection{Taiwan's aging phenomenon and demand for care services}

Aging populations in advanced societies is the trend in the 21 st century; it will have a major impact on social systems and lifestyles. According to the definition of the WHO, a country enters an aging society when its population over 65 years of age exceeds $7 \%$ of the total population; it enters an aged society when its population over 65 years of age exceeds $14 \%$ of the total population, and it enters a super-aged society when its population over 65 years of age exceeds $20 \%$ of the total population. The aging population of Taiwan went beyond 14\% in March 2018, at which time Taiwan officially became an aged society. It will take only eight years to transform from an aged society into a super-aged society. It is estimated that by 2026 Taiwan will officially become a super-aged society (National Development Council, 2018a).

In the future, the proportion of the population over 65 years old to that of the total population will increase year by year. The elderly population exceeded the infant population in 2017. It is estimated that by 2065 the elderly population will be 4.5 times that of the infant population. In addition, the median age in Taiwan was 41.6 years old in 2018. It is estimated that it will be over 50 years old in 2034, which means that about half of the people will be over 50, and that figure will rise to 57.8 years old in 2065 (National Development Council, 2018b). Therefore, the degree of aging will continue to increase. According to the above data, Taiwan's population structure is gradually reversing. Due to the sharp increase of the elderly population and the gradual decrease of the young population, the proportion of elderly residents that young adults need to support is also gradually increasing. Therefore, the establishment of a consummate care services to meet the needs of the elderly has become one of the keys to develop the social welfare system for the government (The Executive Yuan, 2018).

Daytime care is one form of residential care in which the elderly can receive care near their homes instead of having to move. They can go to daily care centers for the aged during the day and return home to their families at night. Aging in place is the goal of promoting long-term care policies in various countries, in which home-based and community-based services are priorities. The U.S. Department of Health and Human Services has identified the basic goals of social adult day care services as the provision of a safe environment, assistance in activities of daily living, and therapeutic activities, which can help program participants achieve optimal physiological and psychological functions (Abramson, 2009). In Japan, day care is a designated home service. Its purpose is to keep users at home as much as possible, even if they are in need of care, to maintain their independence according to their residual abilities, eliminate their sense of social isolation, maintain their physical and mental functions, and reduce the physical and mental burdens of their families through the provision of daily life care and functional training (Hsieh, 2018).

The government of Taiwan began providing awards in 1987 to assist county and municipal governments, as well as public and private elderly care institutions, in handling day care for the elderly, in providing venues for the functional training of the elderly and necessary assistance in daily life (Shao, 2010), which includes a hybrid system of residential day care service for the elderly with disabilities, dementia, and the combination of disability and dementia. However, taking Taipei as an example, the number of daily care centers for the aged is still facing a serious shortage.

\subsection{Taiwan's low birth rate and corresponding policies}

According to the DSMI, it was estimated that the number of secondary and elementary school students would decrease from 2.5 million in 2009 to 1.8 million in 2016, representing a decrease of nearly $30 \%$ in just seven years. As of 2019, 199 secondary and elementary schools in Taipei City and 479 classrooms have become idle after a preliminary evaluation by the Department of Education (Department of Education, Taipei City Government, 2019). In other words, as the birth rate continues to decline and the number of students decreases, the number of secondary and elementary school students in the country will continue decreasing year by year. According to the estimation of the Architecture and Building Research Institute of 
the Ministry of the Interior, the total number of classes in secondary and elementary schools has decreased by about $20 \%$, respectively (Yu, 2013).

The above facts suggest that the reuse of vacant campus spaces should be given full play. Since 2003, the Ministry of Education has implemented the "Demonstration Plan for Activation and Reuse of Vacant Space in School Buildings"; it began promoting the "Vacant Public Facilities Promotion Program" in 2006 and launched the "Activation of Public Facilities Vacant Space and Prevention Strategies" in 2014 (Lin \& Lin, 2015). Based on the concept of sharing resources between schools and communities, spare classrooms in schools can be converted for other uses according to the actual needs of local community residents and the concept of compound school facilities (Yu, 2013). In response to the social development needs of the aged and the low birth rate, the government can meet the urgent demand for care services for the aged by transforming public venues, such as activity centers, primary school buildings, markets, health centers, and other types of buildings, into daily care centers for the aged.

\section{Daily aged care center site selection assessment factors}

Compared with other idle spaces, the secondary and elementary school buildings in a community are legal public venues, and most of them are located in the core of the community. If they are turned into daily care centers for the aged, they can effectively be combined with the resources and living facilities in the surrounding communities. This will enable the elderly to receive good care without being far away from home or needing to adjust to unfamiliar living quarters, and they can return to their familiar homes at night. There are cases at home and abroad that have focused on turning secondary and elementary school buildings in residential areas into daily care centers for the aged (Chen, 2017). Alley et al. (2007) stated that the environment of a friendly residential area for the elderly must have conditions such as convenient transportation, housing, medical care, safety, and community participation. Lai et al. (2016) believed that improving transportation services could slow down the elderly's active aging and maintain the connection with the community. In addition, recreational activities and convenient medical services are age-friendly features that can assist the adult groups in a physical environment. WHO (2007) also presented an age-friendly cities guide, in which an age-friendly city can encourage active aging by optimizing opportunities for health, participation, and security in order to enhance quality of life. Cramm et al. (2013) indicated that receiving social support and having interdependent neighborhoods are important to the elderly. Another study lists six design dimensions that have a significant impact on the quality of a friendly environment for elderly individuals with diminished mental capacities: familiarity, legibility, distinctiveness, accessibility, comfort, and safety (Mitchell et al., 2003). The above-mentioned studies re- vealed that the activities and location in the community will indirectly affect the elderly's feelings of the environment, and the importance of the location of the community-based daily care centers for the aged. Therefore, the first dimension related to site selection assessment could be the quality of the "Community environment".

Apart from the community environment, the conditions around the site are also important. The environmental barriers subjectively reported by older adults include poor transportation, discontinuous or uneven sidewalks, noise, and inadequate lighting, need to be improved for the aged society (Markham \& Gilderbloom, 1998; Debnam et al., 2002; Huang et al., 2010). Mitchell et al. (2004) and Briggs (2004) further indicated that the elderly prefer to go to parks within 300 meters of the surrounding area and prefer more informal spaces, such as streets and parks. The outdoor environment should also consider design (such as planting and fencing) to reduce environmental background noise or traffic noise. Sidewalks and pavement should be made of relatively flat cement, asphalt, or other integrated materials to facilitate walking and jogging (Chou, 2015). Similarly, wide pavements and traffic signals for crossings can also help the aged adapting in the environment (Lai et al., 2016). In addition to the influence of human physical conditions on the body and mind, Witham et al. (2009) also mentioned that the physical activity level of the elderly is much higher in summer than in winter, indicating that sunshine exposure, maximum temperature and wet environment have a significant impact on the level of physical activity. Therefore, the surroundings of the site should contain natural environment qualities and other conditions that can create peace of mind and safety for the elderly. Therefore, the second dimension related to site selection assessment could be the quality of "Outdoor physical environment".

The Ministry of the Interior of Taiwan proposed planning and design criteria for daily care centers for the aged in 2013; they included listing the design criteria for daily care centers for the aged, such as a building's exterior appearance and interior space vision, lighting, ventilation, sound insulation, temperature regulation quality, entrance and exit design, facility design, road signs, and other factors. In addition, The Construction and Planning Agency of Taiwan (2018) announced that the application of the original residential barrier-free facility improvement plan should set the priority order according to the age of house buildings, the type of buildings, etc. Wu et al. (2004) also found that housing quality would have a statistically significant impact on the health of the elderly. Chan et al. (2016) suggested that the government should have subsidized programs to allow the elderly to modify the barrier-free facilities inside the apartment so that they could become more age-friendly. Thus, the elderly's housing and spaces have to be emphasized considering building age-friendly environments (Lai et al., 2016). An appropriate building environment, space composition, and environmental planning and design are all environmental conditions that contribute to the elderly's quality of life. 
Therefore, the third dimension related to site selection assessment could be the quality of "Indoor and built environment".

Based on the above studies, this study preliminarily summarized the site selection condition assessment of daily care centers for the aged into three dimensions: community environment, outdoor physical environment, and indoor and built environment. We have attempted to summarize and organize the site selection assessment according to the three dimensions and above-mentioned existing literature to produce 9 factors and 23 indicators, as shown in Table 1.

Table 1. Indicators literature index

\begin{tabular}{|c|c|c|c|c|c|c|c|c|c|c|c|c|c|c|c|c|c|c|}
\hline Dimensions & \multicolumn{2}{|c|}{ Factors and indicators } & 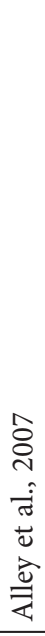 & 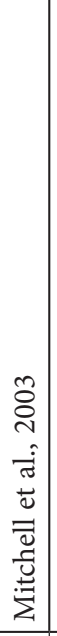 & 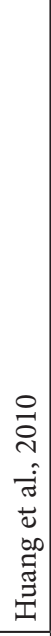 & 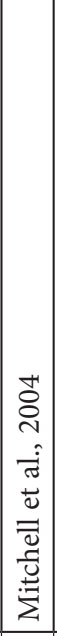 & $\begin{array}{l}+ \\
\delta \\
\delta \\
0 \\
0 \\
.00 \\
.00 \\
0\end{array}$ & 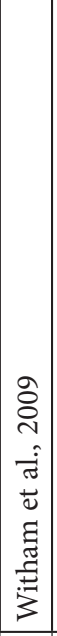 & 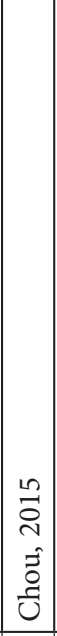 & 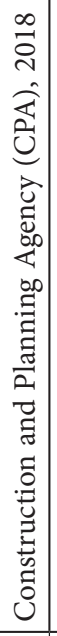 & 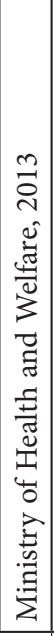 & 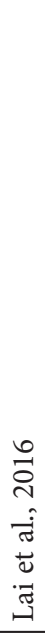 & 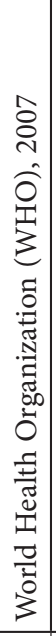 & 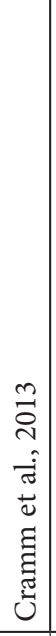 & 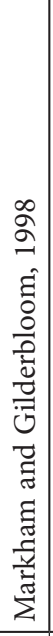 & 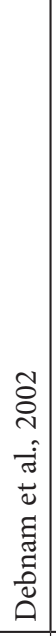 & 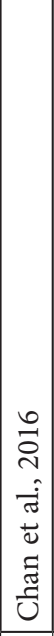 & 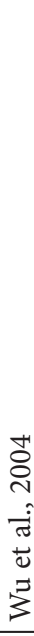 \\
\hline \multirow{7}{*}{$\begin{array}{l}\text { Community } \\
\text { environment }\end{array}$} & \multirow{2}{*}{$\begin{array}{l}\text { Medical } \\
\text { resources }\end{array}$} & Medical convenience & $\bullet$ & & & & & & & & & $\bullet$ & & & & & & \\
\hline & & Medical repeatability & $\bullet$ & & & & & & & & & $\bullet$ & & & & & & \\
\hline & \multirow{2}{*}{$\begin{array}{l}\text { Regional } \\
\text { transportation }\end{array}$} & Traffic accessibility & $\bullet$ & $\bullet$ & & & & & & & & $\bullet$ & & & $\bullet$ & $\bullet$ & & \\
\hline & & Traffic convenience & $\bullet$ & $\bullet$ & & & & & & & & $\bullet$ & & & & & & \\
\hline & \multirow{3}{*}{$\begin{array}{l}\text { Humanistic } \\
\text { activities }\end{array}$} & Identity & & $\bullet$ & & & & & & & & & & $\bullet$ & & & & \\
\hline & & Familiarity & & $\bullet$ & & & & & & & & & & $\bullet$ & & & & \\
\hline & & Activity & $\bullet$ & & & & & & & & & $\bullet$ & $\bullet$ & & & & & \\
\hline \multirow{7}{*}{$\begin{array}{l}\text { Outdoor } \\
\text { physical } \\
\text { environment }\end{array}$} & \multirow{2}{*}{$\begin{array}{l}\text { Sunshine } \\
\text { condition }\end{array}$} & Hours of sunshine & & $\bullet$ & & & & $\bullet$ & & & & & & & & & & \\
\hline & & Sunshine area & & $\bullet$ & & & & $\bullet$ & & & & & & & & & & \\
\hline & \multirow{3}{*}{$\begin{array}{l}\text { Environmental } \\
\text { noise }\end{array}$} & Adjacent to trunk road & & & $\bullet$ & $\bullet$ & $\bullet$ & & & & $\bullet$ & & & & $\bullet$ & $\bullet$ & & \\
\hline & & $\begin{array}{l}\text { Near the metro/bus station, } \\
\text { railway }\end{array}$ & & & $\bullet$ & $\bullet$ & $\bullet$ & & & & $\bullet$ & & & & $\bullet$ & $\bullet$ & & \\
\hline & & Near commercial spaces & & & $\bullet$ & $\bullet$ & $\bullet$ & & & & $\bullet$ & & & & $\bullet$ & $\bullet$ & & \\
\hline & \multirow[t]{2}{*}{ Barrier-free space } & Clear width of traffic lanes & & & & & & & $\bullet$ & & & $\bullet$ & & & $\bullet$ & $\bullet$ & & \\
\hline & & Sidewalk pavement & & & & & & & $\bullet$ & & & $\bullet$ & & & $\bullet$ & $\bullet$ & & \\
\hline \multirow{9}{*}{$\begin{array}{l}\text { Indoor } \\
\text { and built } \\
\text { environment }\end{array}$} & \multirow{3}{*}{$\begin{array}{l}\text { Campus general } \\
\text { condition }\end{array}$} & Green space area & & & & $\bullet$ & $\bullet$ & & & & & & & & & & & \\
\hline & & Wandering space & $\bullet$ & & & & & & & & & $\bullet$ & & & & & & \\
\hline & & Campus space available & & & $\bullet$ & & & & & & & $\bullet$ & & & & & & \\
\hline & \multirow{3}{*}{$\begin{array}{l}\text { General } \\
\text { condition of } \\
\text { school buildings }\end{array}$} & Age of school buildings & & & & & & & & $\bullet$ & & & & & & & & $\bullet$ \\
\hline & & Service life & & & & & & & & $\bullet$ & & & & & & & & $\bullet$ \\
\hline & & Available classrooms & $\bullet$ & & & & & & & & & $\bullet$ & & & & & & \\
\hline & \multirow{3}{*}{$\begin{array}{l}\text { Day care } \\
\text { classroom } \\
\text { potential }\end{array}$} & Barrier-free spaces & & & $\bullet$ & & & & & & & & & & & & $\bullet$ & \\
\hline & & Sunlight and daylight & & $\bullet$ & & & & $\bullet$ & & & $\bullet$ & & & & $\bullet$ & $\bullet$ & & \\
\hline & & Ventilation condition & & $\bullet$ & & & & $\bullet$ & & & $\bullet$ & & & & & & & \\
\hline
\end{tabular}




\section{Methodology}

\subsection{AHP}

AHP is a decision-making method that decomposes a complex multi-criteria decision-making problem (MCDM) into hierarchical structures (Saaty, 1990). AHP uses pairwise comparisons for measurement and relies on the judgments of experts to derive priority scales. The traditional AHP requires that decision makers remain consistent in making pairwise comparisons among numerous decision criteria. Some limitations, such as the difficulty of using discrete scales to reflect the belief of decision makers in the relative importance among the various criteria, have been pointed out regarding the weakness of AHP in making inconsistent judgments (Lin et al., 2008a). However, Satty (2003) insisted that AHP should allow for a modicum of inconsistency because in making judgments people are more likely to be cardinally inconsistent than cardinally consistent because they cannot estimate precise measurement values even from a known scale, and worse, when they deal with intangibles and ordinal intransitive values. In other words, if one can improve the validity of the judgments in the real world, AHP is still a simple and powerful tool for decision-making (Forman \& Gass, 2001).

The calculation procedure of AHP is shown below. According to Rajak and Shaw (2019), a set of criteria can be assumed as $C=\left\{C_{j} / j=1,2,3 \ldots n\right\}$. The pairwise comparison on $\mathrm{n}$ criteria can be summarized in a $(n \times n)$ evaluation matrix $A$. Every component $a_{i j}(i, j=1,2 \ldots n)$ of the matrix $A$ denotes the weight of the criteria given by the decision maker.

The number of pairwise comparisons can be determined according to formula $\frac{n^{2}-n}{2}$, if " $n$ " criteria are considered in the model. Equation (1) represents a matrix for pairwise comparison.

$$
\mathrm{A}=\left[\begin{array}{ccc}
a_{11} & \cdots & a_{1 n} \\
\vdots & \ddots & \vdots \\
a_{n 1} & \cdots & a_{n n}
\end{array}\right], a_{i i}=1, a_{j i}=\frac{1}{a_{j i}}, a_{i j} \neq 0 .
$$

After pairwise comparisons, mathematical calculations are performed to establish the relative weights of criteria. First, a normalized eigenvector $A$ is calculated from a given matrix. Then, the relative weights are given by the eigenvector $(w)$ corresponding to the largest eigenvalue $\left(\lambda_{\max }\right)$, as

$$
A_{W}=\lambda_{\text {max }} w \text {. }
$$

Consistency is an important factor in AHP. The quality of the AHP results and the consistency of the pairwise comparison judgements are strictly related with each other (Hsieh et al., 2018). To check the consistency of the comparison matrix, a consistency index (C.I.) is calculated, as expressed in Equation (3).

$$
\text { C.I. }=\frac{\lambda_{\max }-n}{n-1} \text {. }
$$

Finally, the consistency ratio (C.R.) is calculated. The measurement of the final consistency ratio (C.R.) is to allow researchers to conclude whether the evaluations are sufficiently consistent, which is calculated as the ratio of the consistency index (C.I.) and the random index (R.I.).

$$
\text { C.R. }=\frac{\text { C.I. }}{\text { R.I. }} \text {. }
$$

If the final consistency ratio (C.R.) exceeds the acceptable upper limit of 0.1 , the evaluation process must be repeated to ensure consistency. Both the consistency of decision makers and the overall hierarchy can be assessed by measures of consistency (Dağdeviren et al., 2009).

\subsection{TOPSIS assessment method}

The TOPSIS method is a multi-attribute evaluation method developed by Hwang and Yoon (1981). It is applied to the MCDM method under certain conditions, and the relative distance between the best and worst products in comparison is used to evaluate the superiority of the ranking scheme.

The basic concept of TOPSIS is to first define the Positive Ideal Solution (PIS) and Negative Ideal Solution (NIS). It assumes that each criterion is monotonically increasing or decreasing, i.e., if benefit criteria are being investigated, the greater the performance value, the greater the preference value. On the contrary, if cost criteria are being investigated, the smaller the performance value, the larger the preference value. Therefore, the positive ideal solution collects the best values of all criteria. In contrast, the negative ideal solution consists of the worst values of all criteria. The calculation steps are as follows (Opricovic \& Tzeng, 2004):

Step 1: integration of all measurement data.

The TOPSIS method uses the geometric average calculation to integrate the opinions of numerous people. The integrated result is the initial decision matrix.

Step 2: normalized decision matrix.

The unit of the matrix obtained in the previous step is converted into the same unit for comparison. If $V_{i j}$ is used to represent the evaluation performance value of the normalized decision matrix $(R)$, then $R=\left[V_{i j}\right]$.

Step 3: establishment of weighted matrix standard $(V)$.

Normalized matrix $V=\left[V_{i j}\right] m \times n$, where $V_{i j}=W_{j}$. $R_{i j}$ is the performance value of the weighted evaluation matrix, $W_{j}$ is the weight of the $j$ th attribute, and $\sum_{J=1}^{n} W_{j}=1$ $V=R \cdot W=\left[\begin{array}{ccc}V_{11} & \cdots & V_{1 n} \\ \vdots & \ddots & \vdots \\ V_{m 1} & \cdots & V_{m n}\end{array}\right]=\left[\begin{array}{ccc}W_{j} V_{11} & \cdots & W_{j} V_{1 n} \\ \vdots & \ddots & \vdots \\ W_{j} V_{m 1} & \cdots & W_{j} V_{m n}\end{array}\right]$

Determine the positive ideal solution $\left(A^{*}\right)$ and the negative ideal solution $\left(A^{-}\right)$

Positive ideal solution $\left(A^{*}\right)$ :

$$
\begin{aligned}
& =\left\{\left\langle\max v_{i j} \mid j \in B\right\rangle \cdot\left\langle\min V_{i j} \mid j \in C\right\rangle\right\} \mid i=1,2, \ldots m \\
& =\left\{V_{i}^{*}, V_{1}^{*}, \ldots \ldots V_{n}^{*}\right\} .
\end{aligned}
$$


Negative ideal solution $\left(A^{-}\right)$:

$$
\begin{aligned}
& =\left\{\left\langle\min v_{i j} \mid j \in B\right\rangle \cdot\left\langle\max V_{i j} \mid j \in C\right\rangle\right\} \mid i=1,2, \ldots m \\
& =\left\{V_{i}^{-}, V_{1}^{-}, \ldots \ldots V_{n}^{-}\right\} .
\end{aligned}
$$

where: $B$ is a set of positive benefit attributes; that is, the larger the better. $C$ is a set formed by cost attributes; that is, the smaller the better.

Step 4: getting the separation measure.

The distances between the two schemes and the ideal solution and negative ideal solution are obtained using the Ohrid formulas (9) and (10). The calculation formula is as follows:

The distance between each alternative and the ideal solution is:

$$
\left(S_{i}^{*}\right)=\sqrt{\sum_{j=1}^{n}\left(V_{i j}-V_{j}^{*}\right)^{2}} .
$$

The distance between each alternative scheme and negative ideal solution is:

$$
\begin{aligned}
& \left(S_{i}^{-}\right)=\sqrt{\sum_{j=1}^{n}\left(V_{i j}-V_{j}^{-}\right)^{2}} . \\
& i=1,2, \ldots \ldots m .
\end{aligned}
$$

Step 5: taking the relative closeness to the ideal solution.

The relative closeness indicator $\left(\right.$ R.C.I. $\left.{ }^{*}\right)$ can help to indicate the advantages and disadvantages of each plan's location. Its significance lies in considering the distance from the ideal solution and the negative ideal solution at the same time to evaluate the desired location. The formula is as follows:

$$
\text { R.C.I. }{ }^{*}=\frac{S_{i}^{-}}{S_{i}^{-}+S_{i}^{*}} .
$$

The relative closeness of all aspects is obtained.

Step 6: ranking plan advantages and disadvantages and decision-making.

According to the relative closeness (R.C.I. ${ }^{*}$ ), the schemes are sorted. The higher the value, the higher the priority of the schemes.

Step 7: making a decision.

Finally, objective decisions can be made according to the priorities learned from the scheme.

\section{Using AHP and TOPSIS approaches for selection assessment}

More discussions regarding the comparison of MCDM methods can be accessed in Dinmohammadi and Shafiee's (2017) and Jato-Espino et al.s (2014) studies. Among MCDM methods, the application of AHP combining TOPSIS approach problems has been widely employed to establish the criteria (weights) and prioritize the alternatives. For example, Lin et al. (2008b) proposed a frame- work that integrated AHP and TOPSIS to assist designers in identifying customer requirements and design characteristics, as well as achieve an effective assessment of the final design solution. In this study, AHP was used to compute the weighting values of customer requirements and design characteristics; TOPSIS was then used to evaluate design criteria and feasible design alternatives. Malili et al. (2012) combined AHP and TOPSIS approaches to support site selection for a lead pollution study; in this study, AHP was adopted to evaluate weights of seven selection criteria, and TOPSIS was applied to determine the optimal site selection among six alternatives. Jayant et al. (2014) developed a decision support system to assist the top management of a company in the selection and evaluation of different reverse logistics service providers by a hybrid approach using AHP and TOPSIS methods. In their study, AHP was used to evaluate the weights of ten criteria, and TOPSIS was then applied to rank nine potential service providers. Chang et al. (2012) proposed both AHP and TOPSIS methods to prioritize the protection of the coastal environment on the Miaoli Coast of Taiwan; the weights of three main criteria and their subcriteria were determined through the AHP method, and twenty-two segments of the Miaoli Coast were ranked according to their protection priority by the TOPSIS method. Dinmohammadi and Shafiee (2017) present an integrated AHP-TOPSIS decision model to evaluate and prioritize various technology transfer strategies for wind turbine systems; in their study, the weights of a number of criteria and sub-criteria were defined by AHP, and the technology transfer strategy alternatives were ranked by TOPSIS.

Based on above-mentioned studies, it is obvious that one of the unique features of integrating AHP with TOPSIS is that it provides a powerful procedure to determine the relative importance of different criteria and prioritize the alternatives based on these weighting criteria. Therefore, a combined AHP and TOPSIS approach is developed in this study to rank the most suitable campuses to be converted into daily care centers for the aged.

\section{Case study for site selection of daily care centers for the aged}

\subsection{Establishment of AHP framework}

The AHP framework developed by this study according to the evaluation dimension, factors and indicators established in Table 2 is shown in Figure 1. The site selection was the first layer of the discussion target. The second layer was the community environment, the outdoor physical environment, and the indoor and built environment, and was divided into medical resources, regional transportation, humanistic activities, sunshine conditions, environmental noise, barrier-free spaces, campus profile, school building profile, and day care classroom potential. The last level had 23 site selection indicators. 
Table 2. Daily care center site selection factors and indicators for the aged

\begin{tabular}{|c|c|c|c|c|}
\hline Dimensions & & \multicolumn{2}{|c|}{ Factors and indicators } & Description \\
\hline \multirow[t]{7}{*}{$\begin{array}{l}\text { Community } \\
\text { environment }\end{array}$} & \multirow{7}{*}{$\begin{array}{l}\text { Activities and } \\
\text { locations in } \\
\text { the community } \\
\text { will indirectly } \\
\text { bring to mind } \\
\text { the feelings } \\
\text { of the elderly } \\
\text { towards the } \\
\text { environment }\end{array}$} & \multirow[t]{2}{*}{$\begin{array}{l}\text { Medical } \\
\text { resources }\end{array}$} & $\begin{array}{l}\text { Medical } \\
\text { convenience }\end{array}$ & $\begin{array}{l}\text { Regular health check-ups and outpatient follow-up } \\
\text { treatment to maintain the health of the elderly and avoid } \\
\text { delays in treatment due to physical discomfort }\end{array}$ \\
\hline & & & $\begin{array}{l}\text { Medical } \\
\text { repeatability }\end{array}$ & $\begin{array}{l}\text { Are there other daily age care centers or long-term care } \\
\text { centers around to avoid duplication of resources? }\end{array}$ \\
\hline & & \multirow[t]{2}{*}{$\begin{array}{l}\text { Regional } \\
\text { transportation }\end{array}$} & $\begin{array}{l}\text { Traffic } \\
\text { accessibility }\end{array}$ & $\begin{array}{l}\text { When healthy elderly individuals go to daily age care } \\
\text { centers alone, they mostly use the public transportation } \\
\text { system }\end{array}$ \\
\hline & & & $\begin{array}{l}\text { Traffic } \\
\text { convenience }\end{array}$ & $\begin{array}{l}\text { Is there parking for family transportation to avoid traffic } \\
\text { congestion caused by temporary parking? }\end{array}$ \\
\hline & & \multirow[t]{3}{*}{$\begin{array}{l}\text { Humanistic } \\
\text { activities }\end{array}$} & Identity & $\begin{array}{l}\text { Community centers and village activity centers can } \\
\text { hold activities or gatherings for the elderly, in which the } \\
\text { volunteers or neighbors involved understood their needs } \\
\text { relatively well }\end{array}$ \\
\hline & & & Familiarity & $\begin{array}{l}\text { Traditional buildings or places are more suitable for the } \\
\text { elderly to get familiar with the activity space, thus allowing } \\
\text { them to have more activities and increase the diversity of life }\end{array}$ \\
\hline & & & Activity & $\begin{array}{l}\text { Vicinity and living with nature are beneficial to promoting } \\
\text { the health of the elderly and easing anxiety }\end{array}$ \\
\hline \multirow[t]{7}{*}{$\begin{array}{l}\text { Outdoor } \\
\text { physical } \\
\text { environment }\end{array}$} & \multirow{7}{*}{$\begin{array}{l}\text { The } \\
\text { surroundings } \\
\text { of the site } \\
\text { contain natural } \\
\text { environment } \\
\text { qualities } \\
\text { and other } \\
\text { conditions } \\
\text { that can create } \\
\text { peace of mind } \\
\text { and safety for } \\
\text { the elderly }\end{array}$} & \multirow[t]{2}{*}{$\begin{array}{l}\text { Sunshine } \\
\text { condition }\end{array}$} & Hours of sunshine & $\begin{array}{l}\text { The length of sunshine is conducive to the physical and } \\
\text { mental health of the elderly; the more sunshine hours they } \\
\text { receive, the less anxiety they will have }\end{array}$ \\
\hline & & & Sunshine area & $\begin{array}{l}\text { Most daily age care centers will introduce natural light so } \\
\text { that the elderly can feel the changes of the day }\end{array}$ \\
\hline & & \multirow[t]{3}{*}{$\begin{array}{l}\text { Environmental } \\
\text { noise }\end{array}$} & $\begin{array}{l}\text { Adjacent to trunk } \\
\text { road }\end{array}$ & $\begin{array}{l}\text { The relatively high noise level will cause the elderly to feel } \\
\text { anxious and uneasy; therefore, traffic congestion in the } \\
\text { vicinity of major roads should be avoided }\end{array}$ \\
\hline & & & $\begin{array}{l}\text { Near the metro/ } \\
\text { bus station, } \\
\text { railway }\end{array}$ & $\begin{array}{l}\text { Areas adjacent to metro/bus stations and rail lines are } \\
\text { mostly noisy with too much crowd flow, thus affecting the } \\
\text { elderly }\end{array}$ \\
\hline & & & $\begin{array}{l}\text { Near commercial } \\
\text { spaces }\end{array}$ & Crowd noise \\
\hline & & \multirow[t]{2}{*}{$\begin{array}{l}\text { Barrier-free } \\
\text { space }\end{array}$} & $\begin{array}{l}\text { Clear width of } \\
\text { traffic lanes }\end{array}$ & $\begin{array}{l}\text { Is there enough space on the sidewalk for the elderly or } \\
\text { those in wheelchairs? }\end{array}$ \\
\hline & & & $\begin{array}{l}\text { Sidewalk } \\
\text { pavement }\end{array}$ & $\begin{array}{l}\text { If the pavement is uneven and damaged, it will be easy to } \\
\text { accumulate water and cause the elderly to slip }\end{array}$ \\
\hline \multirow{9}{*}{$\begin{array}{l}\text { Indoor } \\
\text { and built } \\
\text { environment }\end{array}$} & \multirow{9}{*}{$\begin{array}{l}\text { The } \\
\text { environment } \\
\text { of the campus } \\
\text { itself, including } \\
\text { that of the sites } \\
\text { and buildings }\end{array}$} & \multirow[t]{3}{*}{$\begin{array}{l}\text { Campus general } \\
\text { condition }\end{array}$} & Green space area & $\begin{array}{l}\text { Is there enough green space in the internal environment of } \\
\text { the campus? }\end{array}$ \\
\hline & & & Wandering space & Is there room for wandering? \\
\hline & & & $\begin{array}{l}\text { Campus space } \\
\text { available }\end{array}$ & $\begin{array}{l}\text { The size of the total campus area will indirectly affect the } \\
\text { availability of outdoor or sports spaces on campus }\end{array}$ \\
\hline & & \multirow{3}{*}{$\begin{array}{l}\text { General } \\
\text { condition of } \\
\text { school buildings }\end{array}$} & $\begin{array}{l}\text { Age of school } \\
\text { buildings }\end{array}$ & $\begin{array}{l}\text { The older the school buildings are, the harder it will be to } \\
\text { comply with current barrier-free design regulations }\end{array}$ \\
\hline & & & Service life & $\begin{array}{l}\text { The number of years that the school can continue to be } \\
\text { used will affect the efficiency of building daily age care } \\
\text { centers }\end{array}$ \\
\hline & & & $\begin{array}{l}\text { Available } \\
\text { classrooms }\end{array}$ & $\begin{array}{l}\text { The more classrooms available, the more day care space can } \\
\text { be selected or designed. }\end{array}$ \\
\hline & & \multirow{3}{*}{$\begin{array}{l}\text { Day care } \\
\text { classroom } \\
\text { potential }\end{array}$} & $\begin{array}{l}\text { Barrier-free } \\
\text { spaces }\end{array}$ & Proportion of accessible spaces \\
\hline & & & $\begin{array}{l}\text { Sunlight and } \\
\text { daylight }\end{array}$ & Is there enough sunshine and daylight? \\
\hline & & & $\begin{array}{l}\text { Ventilation } \\
\text { condition }\end{array}$ & Is the ventilation good? \\
\hline
\end{tabular}




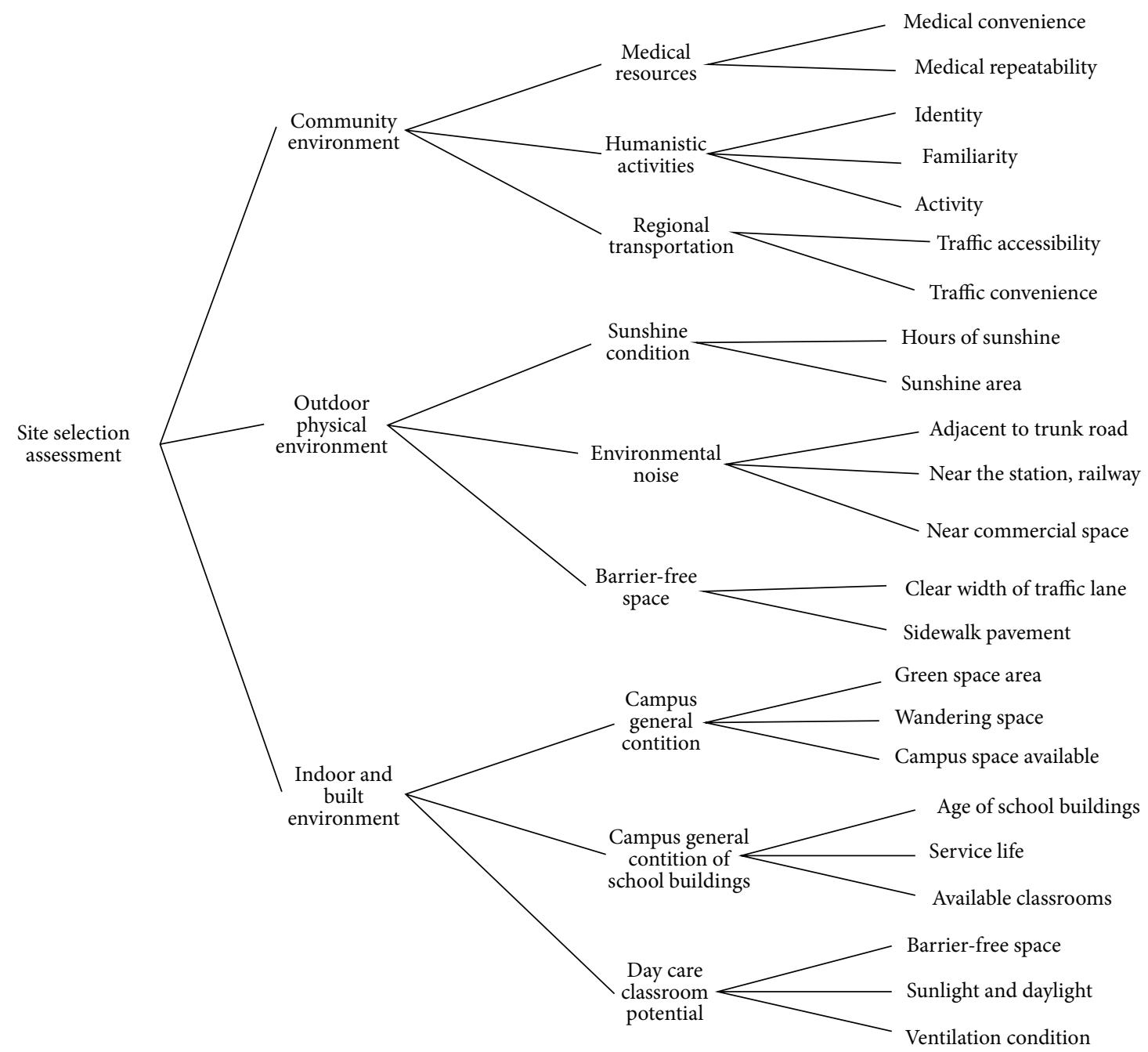

Figure 1. Dimension, factors and indicators for site selection

\subsection{Weights among dimensions, factors, and indicators at different levels}

In this study, four experts with architectural and geriatric professional care backgrounds were invited to fill out questionnaires. Two of them are architects who have participated in building refurbishment and medical facilities design projects in the past 5 years; one is an institute researcher with more than 10 years of study in the field of geriatric care; one is a member of nursing staff who has been working in a daily care center for 8 years. The valid questionnaires after screening were analyzed using software for their continuous integration and consistency ratios. Regarding the screening criteria, if both C.I. and $C . R$. were $\leqq 0.1$, it would indicate conformity criteria and internal consistency. Tables 3-5 list the weights of the first to third levels, respectively.

As shown in the Tables $3-5$, the most advantageous dimension for the site selection was indoor and built environment (0.47), as this had the most direct contact with the lives of the elderly in daily care centers for the aged, followed by community environment (0.36) and outdoor physical environment (0.17). According to the factors and indicators of the second and third levels in the indoor and built environment, the potential factor of day care classrooms was a major consideration for site selection. In other words, whether the existing building environment could be converted into a daily care centers for the aged at the lowest cost or time to reduce the interference with students would be the focus of future conversion. The service life of indoor and built environment (0.075) at the third level showed that the use and service life of buildings are factors of safety consideration for the elderly.

The level 2 and level 3 in the community environment also showed that the convenience factor related to the surrounding traffic was significantly higher than other factors (0.174), which indicated that the convenience for family

Table 3. First level weights and ranking

\begin{tabular}{|l|c|c|}
\hline \multicolumn{1}{|c|}{ Dimensions } & Level weight & Ranking \\
\hline Community environment & 0.36 & 2 \\
\hline Outdoor physical environment & 0.17 & 3 \\
\hline Indoor and built environment & 0.47 & 1 \\
\hline
\end{tabular}

Note: C.I. $=0.02 \leqq 0.1$. 
Table 4. Second level weights and ranking

\begin{tabular}{|c|c|c|c|}
\hline Dimensions & Factors & Level weight & Ranking \\
\hline \multirow{3}{*}{$\begin{array}{l}\text { Community environment } \\
\text { C.I. }=0.1 \leqq 0.1\end{array}$} & Medical resources & 0.31 & 2 \\
\hline & Humanistic activities & 0.19 & 3 \\
\hline & Regional transportation & 0.51 & 1 \\
\hline \multirow{3}{*}{$\begin{array}{l}\text { Outdoor physical environment } \\
\text { C.I. }=0.02 \leqq 0.1\end{array}$} & Sunshine condition & 0.35 & 2 \\
\hline & Environmental noise & 0.25 & 3 \\
\hline & Barrier-free space & 0.41 & 1 \\
\hline \multirow{3}{*}{$\begin{array}{l}\text { Indoor and built environment } \\
\text { C.I. }=0.02 \leqq 0.1\end{array}$} & Campus general condition & 0.24 & 3 \\
\hline & General condition of school buildings & 0.3 & 2 \\
\hline & Day care classroom potential & 0.46 & 1 \\
\hline
\end{tabular}

Table 5. Third level weights and ranking

\begin{tabular}{|c|c|c|c|c|}
\hline Factors & Indicators & Level weight & Absolute weight & Absolute ranking \\
\hline \multirow[t]{2}{*}{ Medical resources } & Medical convenience & 0.92 & 0.104 & 2 \\
\hline & Medical repeatability & 0.08 & 0.009 & 22 \\
\hline \multirow[t]{3}{*}{ Humanistic activities } & Identity & 0.6 & 0.042 & 10 \\
\hline & Familiarity & 0.18 & 0.013 & 19 \\
\hline & Activity & 0.22 & 0.015 & 17 \\
\hline \multirow[t]{2}{*}{ Regional transportation } & Traffic accessibility & 0.06 & 0.011 & 20 \\
\hline & Traffic convenience & 0.94 & 0.174 & 1 \\
\hline \multirow[t]{2}{*}{ Sunshine condition } & Hours of sunshine & 0.83 & 0.049 & 8 \\
\hline & Sunshine area & 0.17 & 0.010 & 21 \\
\hline \multirow[t]{3}{*}{ Environmental noise } & Adjacent to trunk road & 0.19 & 0.008 & 23 \\
\hline & Near the station, railway & 0.34 & 0.014 & 18 \\
\hline & Near commercial space & 0.48 & 0.020 & 15 \\
\hline \multirow[t]{2}{*}{ Barrier-free space } & Clear width of traffic lane & 0.27 & 0.019 & 16 \\
\hline & Sidewalk pavement & 0.73 & 0.051 & 7 \\
\hline \multirow[t]{3}{*}{ Campus general condition } & Green space area & 0.41 & 0.046 & 9 \\
\hline & Wandering space & 0.37 & 0.042 & 11 \\
\hline & Campus space available & 0.23 & 0.026 & 14 \\
\hline \multirow[t]{3}{*}{ General condition of school buildings } & Age of school buildings & 0.21 & 0.030 & 13 \\
\hline & Service life & 0.53 & 0.075 & 4 \\
\hline & Available classrooms & 0.25 & 0.035 & 12 \\
\hline \multirow[t]{3}{*}{ Day care classroom potential } & Barrier-free space & 0.39 & 0.084 & 3 \\
\hline & Sunlight and daylight & 0.29 & 0.062 & 6 \\
\hline & Ventilation condition & 0.33 & 0.071 & 5 \\
\hline
\end{tabular}

members to transport the elderly to and from the hospital on weekdays was also very important. The second factor was the medical convenience factor (0.104) representing the distance from the hospital, which indicated that the convenience for traveling to and from the hospital was also an indispensable factor for the elderly. It could also be seen from Table 5 that the convenience of family transportation, the convenience of traveling to and from the medical treatment location, and the barrier-free space were the top three indicators of the site selection.

\subsection{Daily care centers for the aged site selection rankings using TOPSIS}

In this study, the secondary and elementary schools with the largest number of idle classrooms were selected from each of the 12 administrative districts in the Taipei City area for a site selection assessment (please see Appendix). Table 6 is a description of the indicator quantification, Table 7 presents the evaluation data on the original 12 secondary and elementary schools (Step 1), and the 
second row of brackets is the numerical standardization and weighted matrix (Steps 2-3). The positive and negative ideal solutions (Step 4) are presented in Table 8. Finally, according to the calculation of Steps $5 \sim 7$ of TOPSIS, Table 9 presents the rankings of the school buildings in the 12 secondary and elementary schools. The maximum value of R.C.I. ${ }^{*}$ was 0.7761 , which was categorized as belonging to School $E$, and indicated that it was most suitable for rebuilding into a daily aged care center for the elderly.

Table 6. Numerical description of evaluation criteria

\begin{tabular}{|c|c|c|}
\hline Indicators & Quantitative description & Evaluation unit \\
\hline Medical convenience & $\begin{array}{l}\text { Distance to nearest medical clinic (with medical equipment capable of treating } \\
\text { sudden diseases) }\end{array}$ & Meter \\
\hline Medical repeatability & Distance to nearest daily age care centers or long-term care center & Meter \\
\hline Traffic accessibility & Distance to nearest bus stop or MRT & Meter \\
\hline Traffic convenience & Distance from nearby parking lot & Meter \\
\hline Identity & Distance to nearest community center or activity center & Meter \\
\hline Familiarity & Distance to nearest historical building, traditional market or cultural field & Meter \\
\hline Activity & Distance from the site to the nearest park or venue that is convenient for activities & Meter \\
\hline Hours of sunshine & Calculation for classroom without being blocked by high-rise buildings is six hours & Hour \\
\hline Sunshine area & $\begin{array}{l}\text { The number of buildings exceeding } 15 \text { meters within a radius of } 10 \text { meters around } \\
\text { the site / the total number of buildings around the campus }\end{array}$ & Percentage \\
\hline Adjacent to trunk road & The distance between the school and roads with a width of more than 30 meters & Meter \\
\hline $\begin{array}{l}\text { Near the metro/bus } \\
\text { station, railway }\end{array}$ & The distance from the metro/bus station & Meter \\
\hline Near commercial space & Adjacent to large-scale activity spaces, such as exhibition halls and business circles & Meter \\
\hline Clear width of traffic lane & Pedestrian path width of current site & Meter \\
\hline Sidewalk pavement & $\begin{array}{l}\text { According to the on-site investigation, if the pavement is complete, } 1 \text { point will } \\
\text { be added; if it is not easy to accumulate water, } 1 \text { point will be added. } 0=\text { The } \\
\text { pavement is incomplete and easy to accumulate water; } 1=\text { The pavement is still } \\
\text { intact; } 2=\text { The pavement is complete and not easy to accumulate water }\end{array}$ & Scoring system \\
\hline Green space area & $\begin{array}{l}\text { Check the green area of the campus according to the evaluation content of each } \\
\text { school }\end{array}$ & Square meter \\
\hline Wandering space & $\begin{array}{l}0 \text { = for unidirectional corridors with a width of less than } 1.5 \text { meters; } 1=\text { for } \\
\text { unidirectional corridors with a width of greater than } 1.5 \text { meters; } 2=\text { for circular } \\
\text { corridors with a width greater than } 1.5 \text { meters }\end{array}$ & Scoring system \\
\hline Campus space available & The size of the school's existing space & Square meter \\
\hline Age of school buildings & Years of construction & Year \\
\hline Service life & The number of years that the campus can continue to be used & Year \\
\hline Available classrooms & Number of classrooms available & $\begin{array}{l}\text { Number of } \\
\text { classrooms }\end{array}$ \\
\hline Barrier-free space & $\begin{array}{l}\text { According to the size and the number of accessible facilities in the } 12 \text { schools. } \\
\text { Barrier-free facilities include outdoor guideways, ramps and handrails, refuge } \\
\text { floor entrances, indoor entrances, indoor walkways, ladder, lifting facility, toilet, } \\
\text { bathroom, wheelchair auditorium, parking spaces. } 0=\text { for few facilities ( } 0 \text { to } 3 \\
\text { facilities); } 1 \text { = for appropriate facilities ( } 4 \text { to } 6 \text { facilities); } 2=\text { for many facilities } \\
\text { ( } 7 \text { to } 11 \text { facilities) }\end{array}$ & Scoring system \\
\hline Sunlight and daylight & $\begin{array}{l}0=\text { window area accounts for less than half of the classroom area and has curtain } \\
\text { shade; } 1=\text { window area accounts for about half; } 2=\text { window area accounts for more } \\
\text { than half }\end{array}$ & Scoring system \\
\hline Ventilation condition & $\begin{array}{l}0=\text { for the window area accounts for less than } 1 / 4 \text { of the classroom area; } 1=\text { for } 1 / 4 \\
\text { to half of the area; } 2 \text { = for greater than half }\end{array}$ & Scoring system \\
\hline
\end{tabular}


Table 7. Actual evaluation values and standardization and weighted matrix of various secondary school values

\begin{tabular}{|c|c|c|c|c|c|c|c|c|c|c|c|c|}
\hline \multirow{2}{*}{ Indicators } & \multicolumn{12}{|c|}{12 secondary schools } \\
\hline & $\mathrm{A}$ & $\mathrm{B}$ & $\mathrm{C}$ & $\mathrm{D}$ & $\mathrm{E}$ & $\mathrm{F}$ & G & $\mathrm{H}$ & I & $\mathrm{J}$ & $\mathrm{K}$ & $\mathrm{L}$ \\
\hline \multirow{2}{*}{$\begin{array}{l}\text { Medical } \\
\text { convenience }\end{array}$} & 100 & 3400 & 900 & 950 & 1000 & 600 & 250 & 500 & 600 & 800 & 650 & 500 \\
\hline & $(0.001)$ & $(0.034)$ & $(0.009)$ & $(0.010)$ & $(0.010)$ & $(0.006)$ & $(0.003)$ & $(0.005)$ & $(0.006)$ & $(0.008)$ & $(0.007)$ & $(0.005)$ \\
\hline \multirow{2}{*}{$\begin{array}{l}\text { Medical } \\
\text { repeatability }\end{array}$} & 400 & 3700 & 750 & 2300 & 2700 & 600 & 260 & 500 & 800 & 500 & 750 & 120 \\
\hline & $(0.000)$ & $(0.002)$ & $(0.001)$ & $(0.002)$ & $(0.002)$ & $(0.000)$ & $(0.000)$ & $(0.000)$ & $(0.001)$ & $(0.000)$ & $(0.001)$ & $(0.000)$ \\
\hline \multirow{2}{*}{$\begin{array}{l}\text { Traffic } \\
\text { accessibility }\end{array}$} & 780 & 4020 & 2150 & 390 & 500 & 1120 & 1460 & 640 & 900 & 970 & 940 & 800 \\
\hline & $(0.002)$ & $(0.011)$ & $(0.006)$ & $(0.001)$ & $(0.001)$ & $(0.003)$ & $(0.004)$ & $(0.002)$ & $(0.003)$ & $(0.003)$ & $(0.003)$ & $(0.002)$ \\
\hline \multirow{2}{*}{$\begin{array}{l}\text { Traffic } \\
\text { convenience }\end{array}$} & 300 & 500 & 220 & 170 & 800 & 650 & 10 & 750 & 800 & 30 & 25 & 40 \\
\hline & $(0.001)$ & $(0.001)$ & $(0.001)$ & $(0.001)$ & $(0.002)$ & $(0.002)$ & $(0.000)$ & $(0.002)$ & $(0.002)$ & $(0.000)$ & $(0.000)$ & $(0.000)$ \\
\hline \multirow[t]{2}{*}{ Identity } & 400 & 1400 & 600 & 450 & 700 & 450 & 850 & 850 & 450 & 750 & 500 & 1500 \\
\hline & $(0.001)$ & $(0.002)$ & $(0.001)$ & $(0.001)$ & $(0.001)$ & $(0.001)$ & $(0.001)$ & $(0.001)$ & $(0.001)$ & $(0.001)$ & $(0.001)$ & $(0.003)$ \\
\hline \multirow[t]{2}{*}{ Familiarity } & 400 & 500 & 950 & 1000 & 120 & 950 & 400 & 120 & 950 & 60 & 450 & 500 \\
\hline & $(0.001)$ & $(0.001)$ & $(0.002)$ & $(0.002)$ & $(0.000)$ & $(0.002)$ & $(0.001)$ & $(0.000)$ & $(0.002)$ & $(0.000)$ & $(0.001)$ & $(0.001)$ \\
\hline \multirow[t]{2}{*}{ Activity } & 5 & 5 & 4 & 6 & 1 & 3 & 2 & 6 & 6 & 6 & 3 & 5 \\
\hline & $(0.017)$ & $(0.017)$ & $(0.013)$ & $(0.020)$ & $(0.003)$ & $(0.010)$ & $(0.007)$ & $(0.020)$ & $(0.020)$ & $(0.020)$ & $(0.010)$ & $(0.017)$ \\
\hline \multirow{2}{*}{$\begin{array}{l}\text { Hours of } \\
\text { sunshine }\end{array}$} & 6 & 6 & 6 & 6 & 6 & 6 & 6 & 6 & 6 & 6 & 6 & 6 \\
\hline & $(0.004)$ & $(0.004)$ & $(0.004)$ & $(0.004)$ & $(0.004)$ & $(0.004)$ & $(0.004)$ & $(0.004)$ & $(0.004)$ & $(0.004)$ & $(0.004)$ & $(0.004)$ \\
\hline \multirow[t]{2}{*}{ Sunshine area } & 0.2 & 1 & 0.4 & 0.13 & 0.7 & 0.3 & 0 & 0.83 & 0.1 & 0.2 & 0.3 & 0.1 \\
\hline & $(0.000)$ & $(0.002)$ & $(0.001)$ & $(0.000)$ & $(0.002)$ & $(0.001)$ & $(0.000)$ & $(0.002)$ & $(0.000)$ & $(0.000)$ & $(0.001)$ & $(0.000)$ \\
\hline \multirow{2}{*}{$\begin{array}{l}\text { Adjacent to } \\
\text { trunk road }\end{array}$} & 350 & 1400 & 30 & 150 & 0 & 1800 & 600 & 0 & 450 & 0 & 220 & 160 \\
\hline & $(0.001)$ & $(0.002)$ & $(0.000)$ & $(0.000)$ & $(0.000)$ & $(0.003)$ & $(0.001)$ & $(0.000)$ & $(0.001)$ & $(0.000)$ & $(0.000)$ & $(0.000)$ \\
\hline \multirow{2}{*}{$\begin{array}{l}\text { Near the metro/ } \\
\text { bus station, } \\
\text { railway }\end{array}$} & 12700 & 7700 & 3800 & 1200 & 1200 & 7900 & 600 & 3300 & 950 & 4200 & 1000 & 2600 \\
\hline & $(0.004)$ & $(0.002)$ & $(0.001)$ & $(0.000)$ & $(0.000)$ & $(0.002)$ & $(0.000)$ & $(0.001)$ & $(0.000)$ & $(0.001)$ & $(0.000)$ & $(0.001)$ \\
\hline \multirow{2}{*}{$\begin{array}{l}\text { Near } \\
\text { commercial } \\
\text { spaces }\end{array}$} & 1200 & 4700 & 2800 & 1200 & 450 & 1900 & 550 & 750 & 750 & 1100 & 550 & 500 \\
\hline & $(0.001)$ & $(0.006)$ & $(0.003)$ & $(0.001)$ & $(0.001)$ & $(0.002)$ & $(0.001)$ & $(0.001)$ & $(0.001)$ & $(0.001)$ & $(0.001)$ & $(0.001)$ \\
\hline \multirow{2}{*}{$\begin{array}{l}\text { Clear width of } \\
\text { traffic lane }\end{array}$} & 250 & 120 & 220 & 250 & 190 & 190 & 200 & 380 & 110 & 180 & 240 & 100 \\
\hline & $(0.002)$ & $(0.001)$ & $(0.002)$ & $(0.002)$ & $(0.001)$ & $(0.001)$ & $(0.002)$ & $(0.003)$ & $(0.001)$ & $(0.001)$ & $(0.002)$ & $(0.001)$ \\
\hline \multirow{2}{*}{$\begin{array}{l}\text { Sidewalk } \\
\text { pavement }\end{array}$} & 2 & 0 & 1 & 2 & 1 & 1 & 2 & 2 & 1 & 2 & 1 & 2 \\
\hline & $(0.006)$ & $(0.000)$ & $(0.003)$ & $(0.006)$ & $(0.003)$ & $(0.003)$ & $(0.006)$ & $(0.006)$ & $(0.003)$ & $(0.006)$ & $(0.003)$ & $(0.006)$ \\
\hline \multirow{2}{*}{$\begin{array}{l}\text { Green space } \\
\text { area }\end{array}$} & 3020 & 5232 & 6000 & 4160 & 7550 & 4680 & 3560 & 5000 & 3600 & 3330 & 5090 & 1600 \\
\hline & $(0.003)$ & $(0.005)$ & $(0.005)$ & $(0.004)$ & $(0.007)$ & $(0.004)$ & $(0.003)$ & $(0.004)$ & $(0.003)$ & $(0.003)$ & $(0.004)$ & $(0.001)$ \\
\hline \multirow{2}{*}{$\begin{array}{l}\text { Wandering } \\
\text { space }\end{array}$} & 1 & 0 & 0 & 2 & 2 & 0 & 1 & 2 & 1 & 2 & 1 & 1 \\
\hline & $(0.003)$ & $(0.000)$ & $(0.000)$ & $(0.006)$ & $(0.006)$ & $(0.000)$ & $(0.003)$ & $(0.006)$ & $(0.003)$ & $(0.006)$ & $(0.003)$ & $(0.003)$ \\
\hline \multirow{2}{*}{$\begin{array}{l}\text { Campus space } \\
\text { available }\end{array}$} & 10355 & 25562 & 40559 & 17338 & 26222 & 15647 & 16605 & 20160 & 33923 & 34613 & 24218 & 24834 \\
\hline & $(0.001)$ & $(0.002)$ & $(0.004)$ & $(0.002)$ & $(0.002)$ & $(0.001)$ & $(0.001)$ & $(0.002)$ & $(0.003)$ & $(0.003)$ & $(0.002)$ & $(0.002)$ \\
\hline Age of school & 25 & 38 & 33 & 40 & 50 & 42 & 39 & 45 & 32 & 13 & 12 & 48 \\
\hline & $(0.002)$ & $(0.003)$ & $(0.002)$ & $(0.003)$ & $(0.004)$ & $(0.003)$ & $(0.003)$ & $(0.003)$ & $(0.002)$ & $(0.001)$ & $(0.001)$ & $(0.003)$ \\
\hline Service life & 20 & 20 & 20 & 20 & 20 & 20 & 20 & 20 & 20 & 20 & 20 & 20 \\
\hline & $(0.006)$ & $(0.006)$ & $(0.006)$ & $(0.006)$ & $(0.006)$ & $(0.006)$ & $(0.006)$ & $(0.006)$ & $(0.006)$ & $(0.006)$ & $(0.006)$ & $(0.006)$ \\
\hline & 9 & 10 & 25 & 24 & 40 & 14 & 13 & 23 & 44 & 48 & 10 & 9 \\
\hline & $(0.001)$ & $(0.001)$ & $(0.003)$ & $(0.003)$ & $(0.005)$ & $(0.002)$ & $(0.002)$ & $(0.003)$ & $(0.006)$ & $(0.006)$ & $(0.001)$ & $(0.001)$ \\
\hline Barrier-free & 1 & 0 & 0 & 2 & 2 & 0 & 1 & 2 & 1 & 2 & 1 & 1 \\
\hline & $(0.006)$ & $(0.000)$ & $(0.000)$ & $(0.013)$ & $(0.013)$ & $(0.000)$ & $(0.006)$ & $(0.013)$ & $(0.006)$ & $(0.013)$ & $(0.006)$ & $(0.006)$ \\
\hline Sunlight and & 2 & 2 & 1 & 2 & 2 & 1 & 0 & 1 & 0 & 1 & 2 & 2 \\
\hline & $(0.008)$ & $(0.008)$ & $(0.004)$ & $(0.008)$ & $(0.008)$ & $(0.004)$ & $(0.000)$ & $(0.004)$ & $(0.000)$ & $(0.004)$ & $(0.008)$ & $(0.008)$ \\
\hline & 1 & 1 & 1 & 1 & 2 & 1 & 2 & 1 & 2 & 2 & 1 & 1 \\
\hline & $(0.004)$ & $(0.004)$ & $(0.004)$ & $(0.004)$ & $(0.009)$ & $(0.004)$ & $(0.009)$ & $(0.004)$ & $(0.009)$ & (0.009) & $(0.004)$ & $(0.004)$ \\
\hline
\end{tabular}


Table 8. Positive and negative ideal solutions

\begin{tabular}{|l|c|c|}
\hline \multicolumn{1}{|c|}{ Indicators } & $\mathrm{A}^{\star}$ & $\mathrm{A}^{-}$ \\
\hline Medical convenience & 0.0010 & 0.0344 \\
\hline Medical repeatability & 0.0001 & 0.0025 \\
\hline Traffic accessibility & 0.0011 & 0.0114 \\
\hline Traffic convenience & 0.0000 & 0.0024 \\
\hline Identity & 0.0007 & 0.0026 \\
\hline Familiarity & 0.0000 & 0.0017 \\
\hline Activity & 0.0033 & 0.0200 \\
\hline Hours of sunshine & 0.0041 & 0.0041 \\
\hline Sunshine area & 0.0024 & 0.0000 \\
\hline Adjacent to trunk road & 0.0000 & 0.0028 \\
\hline Near the metro/bus station, railway & 0.0002 & 0.0039 \\
\hline Near commercial space & 0.0006 & 0.0058 \\
\hline Clear width of traffic lane & 0.0029 & 0.0008 \\
\hline Sidewalk pavement & 0.0060 & 0.0000 \\
\hline Green space area & 0.0066 & 0.0014 \\
\hline Wandering space & 0.0064 & 0.0000 \\
\hline Campus space available & 0.0036 & 0.0009 \\
\hline Age of school buildings & 0.0009 & 0.0036 \\
\hline Service life & 0.0062 & 0.0062 \\
\hline Available classrooms & 0.0063 & 0.0012 \\
\hline Barrier-free space & 0.0129 & 0.0000 \\
\hline Sunlight and daylight & 0.0077 & 0.0000 \\
\hline Ventilation condition & 0.0088 & 0.0044 \\
\hline
\end{tabular}

Table 9. $A^{\star}, A^{-}$and R.C.I. ${ }^{\star}$ values

\begin{tabular}{|c|c|c|c|c|}
\hline Schools & $A^{*}$ & $A^{-}$ & R.C.I. $^{*}$ & Rank \\
\hline A & 0.0179 & 0.03744 & 0.6761 & 4 \\
\hline B & 0.0418 & 0.00969 & 0.1880 & 12 \\
\hline C & 0.0217 & 0.02824 & 0.5655 & 11 \\
\hline D & 0.0203 & 0.03288 & 0.6186 & 9 \\
\hline E & 0.0107 & 0.03697 & 0.7761 & 1 \\
\hline F & 0.0197 & 0.03205 & 0.6194 & 8 \\
\hline G & 0.0136 & 0.03765 & 0.7344 & 2 \\
\hline H & 0.0190 & 0.03581 & 0.6532 & 5 \\
\hline I & 0.0215 & 0.03227 & 0.6007 & 10 \\
\hline J & 0.0192 & 0.03370 & 0.6369 & 7 \\
\hline K & 0.0140 & 0.03394 & 0.7087 & 3 \\
\hline L & 0.0185 & 0.03408 & 0.6478 & 6 \\
\hline
\end{tabular}

\subsection{Results and discussion}

The above results indicate that the secondary and elementary school buildings in region $E$ ( $E$ project) should be given priority for conversion into daily care centers for the aged. Some factors and indicators made the E project more prominent. For example, considering the Community environment dimension, the indicators of medical repeatability, traffic accessibility, familiarity, and activity of the $E$ project are more advantageous than indicators of other projects. These results are similar to some studies revealing the importance of living convenience and necessity of nostalgic psychology for the elderly and their families (Alley et al., 2007; Butler, 1963). In other words, familiar relatives and friends, as well as former residences enable the elderly to obtain higher spiritual and life satisfaction. After the investigation, we found that there were some surrounding places, such as traditional markets, parks and greenbelts, and historical buildings, near the $E$ project (as shown in Figure 2) that can really reflect the importance of the elderly's expectations to be accepted and recognized by society.

As for the Outdoor physical environment dimension, the $E$ project has the highest evaluation for the indicators of sunshine condition. Although the $E$ project has disadvantages in the environmental noise factors, the result was not significantly influenced due to their low weights of indicators. Table 3 proves that the Outdoor physical environment dimension has less impact on the site selection assessment. The results are partly inconsistent with previous studies stating that the elderly prefer to go to parks, and emphasizing the conditions of sidewalks and pavement in the surrounding area (Mitchell et al., 2004; Briggs, 2004; Chou, 2015). It is inferred that the elderly feel indifferent to these indicators because they can still have wandering and green space access on campus (next dimension of Indoor and built environment) and would avoid taking a risk walking and wandering off campus.

The Indoor and built environment dimension has the highest impact on the site selection assessment. The results, as shown in Figure 3, indicate that the $E$ project has the better evaluation for the indicators of green space, barrier-free space, the sunlight and daylight, wandering space, and ventilation conditions than other projects do. It is reasonable that an appropriate building environment, space composition, and environmental planning and design are environmental conditions that contribute to the elderly's quality of life. This assumption can also be supported by the findings of some studies regarding the design for quality of life for the elderly (Witham et al., 2009; Mitchell et al., 2004; Briggs, 2004).

Facing the severe social problems of an aging population coupled with a low birth rate, the Taiwan government has been strenuously proposing relevant policies and strategies to deal with the reuse of vacant campus spaces. For example, under the program of "10-year long-term care 2.0 plan", the Taipei City government has established 477 small-sized community-based care stations since 2016. With these stations, more than 15.000 people with disabilities and dementia can receive daily care services. However, the accommodation of current stations and daily care centers only accounts for $13 \%$ of the aged with disabilities and dementia. It is estimated that there is still high demand (e.g. at least 100.000 people) for daily care centers for the aged in the near future. The proposed methodology combining AHP and TOPSIS could be an effective tool that may quickly solve the complex decision-making problems regarding site selection assessment. Even in the following stages after site selection, the proposed methodology can still be used to evaluate the priority of planning and design alternatives. 

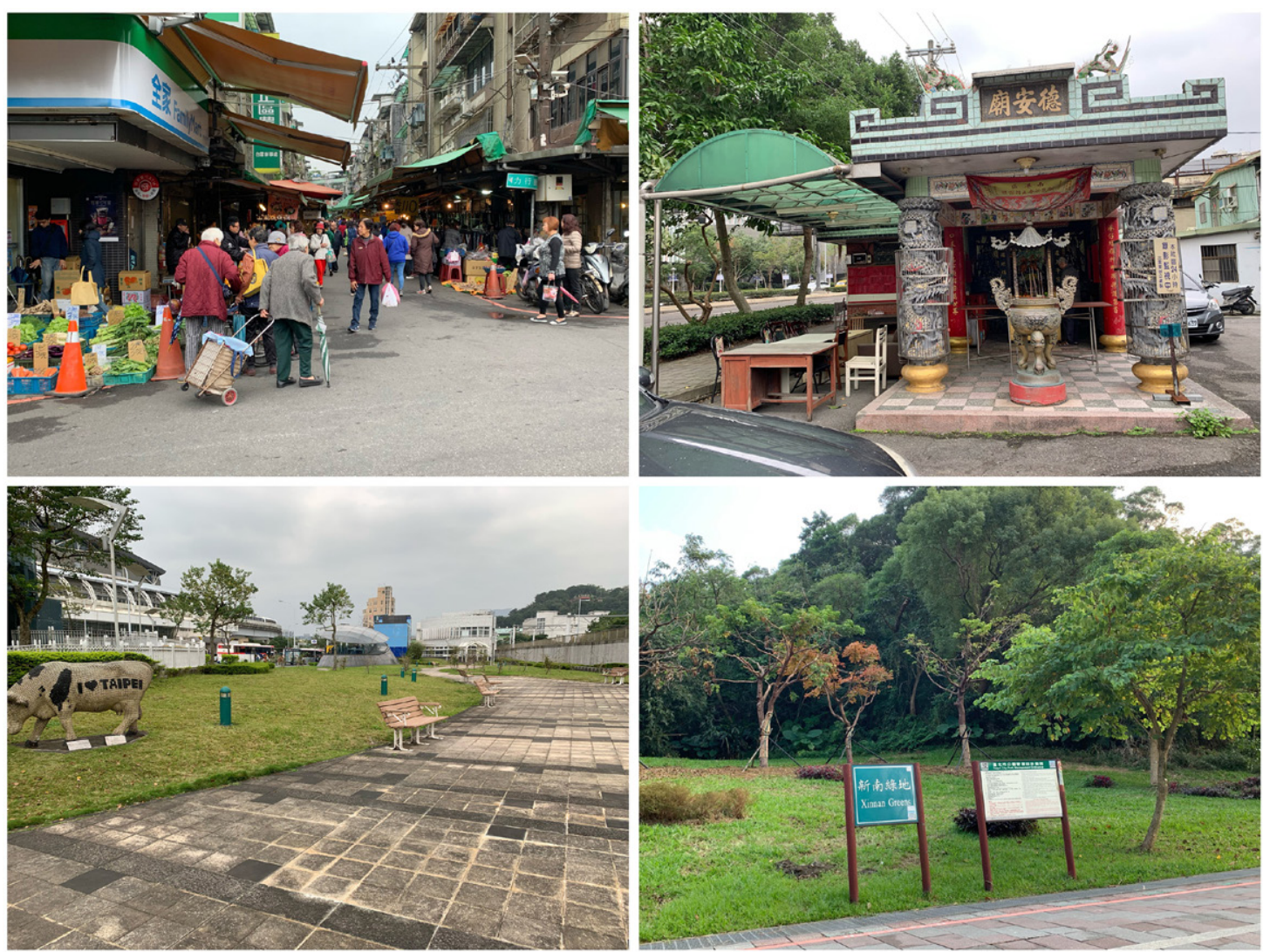

Figure 2. Surroundings of community environment
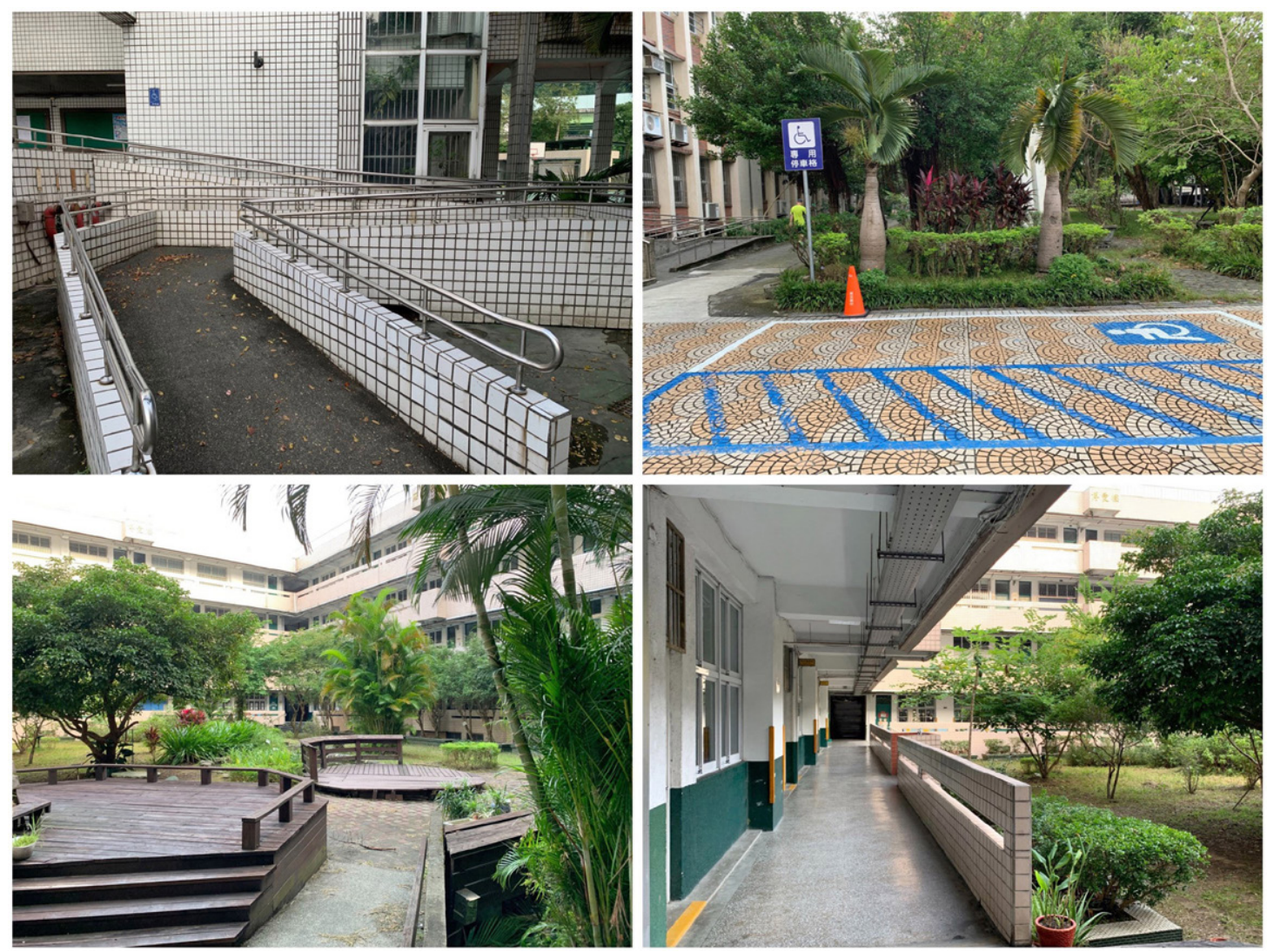

Figure 3. Facilities of indoor and built environment 


\section{Conclusion and suggestions}

In order to meet the social development trend of aging and a low birth rate, and after considering the current number and potential demand of daily care centers for the aged in Taiwan, this study found that reusing vacant campuses as daily care centers for the aged is a win-win strategy for future policy promotion. On the one hand, it can provide sufficient space to meet the demand for elderly care; on the other hand, it can effectively solve the problem of an increasing number of idle school buildings due to the low birth rate. The three-stage site selection evaluation method proposed by this study, from the construction of site selection indicators and weight analysis to the selection of actual plans, preliminarily sorts the important factors to be considered during the site selection of daily care centers for the aged and the feasibility of future decision-making plans. The research results show that convenient transportation by family members, the convenience of returning to and from medical treatment facilities, the service life of school buildings, barrier-free spaces, and ventilation condition are important factors. Actual case evaluations show that the proposed method could effectively assist decisionmaking and planning regarding the reuse of vacant spaces in the future.

From the environmental aspect of sustainable development, the issue of converting vacant school buildings into daily care centers for the aged, as proposed by this study, could prolong the service life of the buildings and reduce unnecessary demolition and construction through reuse, which is helpful for improving the sustainability of buildings and the urban environment. From the social perspective, reused vacant school spaces can quickly address the urgent social needs of long-term care for the elderly and can effectively improve the quality of life of the elderly in the future. From the economic point of view, through appropriate site selection and decision evaluations, poor government decisions and inappropriate resource allocations can be effectively reduced. To sum up, the precise building reuse processes and decision-making can ensure the success of a project that can benefit society, the economy, and the environment through sustainability.

However, there are still some limitations to the application of the methods proposed in this study. First, the cases used in this study were limited to Taipei, Taiwan. Different regions or cities may have different assessment needs, and the assessment indicators need to be reviewed or adjusted. Second, this study was limited to the site selection stage of daily care centers for the aged. Further discussion is still needed regarding how to develop relevant planning and design concepts, feasibility, finance and risk assessment of the project after site selection to meet the actual needs of daily care centers for the aged in the future. It is suggested that the government may refer to the method proposed in this study to conduct a large-scale site selection assessment and effectively solve the problem of vacant space reuse, thereby accelerating the Taiwan government's future goal of promoting long-term care for the aged.

\section{Acknowledgements}

The authors appreciate the valuable comments from editors and anonymous reviewers. Their detailed comments helped to improve the clarity and focus of this study. The authors are also grateful for the funding supported by the Taiwan Building Technology Center from The Featured Areas Research Center Program within the framework of the Higher Education Sprout Project by the Ministry of Education (MOE) in Taiwan.

\section{References}

Abramson, C. M. (2009). Who are the clients? Goal displacement in an adult day care center for elders with dementia. Aging and Human Development, 68(1), 65-92.

https://doi.org/10.2190/AG.68.1.d

Alley, D., Liebig, P., Pynoos, J., Banerjee, T., \& Choi, I. H. (2007). Creating elder-friendly communities: preparations for an aging society. Journal of Gerontological Social Work, 49(1-2), 1-18. https://doi.org/10.1300/J083v49n01_01

Briggs, J. (2004). Dementia care and the built environment position paper 3 (pp. 6-13). Alzheimer's Australia.

Butler, R. N. (1963). The life review: an interpretation of reminiscence in the aged. Psychiatry, 26(1), 65-76. https://doi.org/10.1080/00332747.1963.11023339

Chan, A. W. K., Chan, H. Y. L., Chan, I. K. Y., Cheung, B. Y. L., \& Lee, D. T. F. (2016). An age-friendly living environment as seen by Chinese older adults: a "photovoice" study. International Journal of Environmental Research and Public Health, 13(9), 913. https://doi.org/10.3390/ijerph13090913

Chang, H. K., Liou, J. C., \& Chen, W. W. (2012). Protection priority in the coastal environment using a hybrid AHP-TOPSIS method on the Miaoli Coast, Taiwan. Journal of Coastal Research, 28(2), 369-374.

https://doi.org/10.2112/JCOASTRES-D-10-00092.1

Chen, P. T. (2017). Revitalization of idle space for daycare for the elderly research (Commissioned research report by the Institute of Architecture of the Ministry of the Interior). https:// www. abri.gov.tw/tw/research/dl/2672/1 (in Chinese)

Chou, Y. M. (2015). Old people's needs for community landscapes and public spaces. China Real Estate News. http://www. chla.com.cn/htm/2014/0421/207129.html (in Chinese)

Construction and Planning Agency. (2018). The application of original residential barrier-free facility improvement plan. https://pip.moi.gov.tw/Upload/File/Policy/6306bead-5e184844-ab8b-808f3470efe9.pdf (in Chinese)

Cramm, J. M., VanDijk, H. M., \& Nieboer, A. P. (2013). The importance of neighborhood social cohesion and social capital for the well being of older adults in the community. Gerontologist, 53(1), 142-152. https://doi.org/10.1093/geront/gns052

Dağdeviren, M., Yavuz, S., \& Kilinç, N. (2009). Weapon selection using the AHP and TOPSIS methods under fuzzy environment. Expert Systems with Applications, 36(4), 8143-8151. https://doi.org/10.1016/j.eswa.2008.10.016

Debnam, K., Harris, J., Morris, I., Parikh, S., \& Shirey, L. (2002). Durham County socially isolated older adults: an action-oriented community diagnosis. University of North Carolina at Chapel Hill School of Public Health, Department of Health Behavior and Health Education.

Department of Education, Taipei City Government. (2019). The remaining space situation of the national primary and secondary schools in Taipei City. https://www.doe.gov.taipei/News_ 
Content.aspx?n=014F31463F0A3BD5\&sms=69B4E6B26379E E4E\&s=BD85DC4F9BB23B88 (in Chinese)

Department of Social Welfare, Taipei City Government. (2016). The day care center in the North City has added temporary residential multi-care services. https://dosw.gov.taipei/News_ Content.aspx? $\mathrm{n}=$ B6EBAF8221E26F34\&sms=A84DFFE0D64 ADCBA\&s $=8$ CBA53D289962912 (in Chinese)

Department of Statistics, Ministry of the Interior. (2016). Fertility rate, general fertility rate, total fertility rate, and fertility rate of husband and woman. Vital statistics. https://www.stat.gov.tw/ct .asp? $x$ Item $=15409 \&$ CtNode $=3622 \& \mathrm{mp}=4$ (in Chinese)

Department of Statistics, Ministry of the Interior. (2018). Week 15 internal affairs statistics bulletin. 2018 elderly population statistics. https://www.moi.gov.tw/stat/news_detail. aspx?sn=13742 (in Chinese)

Dinmohammadi, A., \& Shafiee, M. (2017). Determination of the most suitable technology transfer strategy for wind turbines using an integrated AHP-TOPSIS decision model. Energies, 10, 642. https://doi.org/10.3390/en10050642

Forman, E. H., \& Gass, S. I. (2001). The analytic hierarchy process - an exposition. Operations Research, 49(4), 469-486. https://doi.org/10.1287/opre.49.4.469.11231

Hsieh, M., Wang, E. M., Lee, W., Li, L., Hsieh, C., Tsai, W., Wang, C., Huang, J., \& Liu, T. (2018). Application of HFACS, fuzzy TOPSIS, and AHP for identifying important human error factors in emergency departments in Taiwan. International Journal of Industrial Ergonomics, 67, 171-179.

https://doi.org/10.1016/j.ergon.2018.05.004

Hsieh, W. C. (2018). Take care of the zero time difference - community day care centre. Health News KMUH, 38(4). http:// www.kmuh.org.tw/www/kmcj/data/10709/16.htm (in Chinese)

Huang, X. W., Wu, P. Y., \& Chen, B. Z. (2010). Analysis and Research on the Planning and Setting of Day Care Center for the Elderly-Take Tainan City Jianping and Lin'an Day Care Centers as examples. Taiwanese Gerontological Forum, 5. http://bbc035r.web3.ncku.edu.tw/var/file/169/1169/ img/3713/872629640.pdf (in Chinese)

Hwang, C. L., \& Yoon, K. (1981). Multiple attribute decision making: methods and applications. Springer-Verlag.

https://doi.org/10.1007/978-3-642-48318-9

Jato-Espino, D., Castillo-Lopez, E., Rodriguez-Hernandez, J., \& Canteras-Jordana, J. C. (2014). A review of application of multi-criteria decision making methods in construction. Automation in Construction, 45, 151-162.

https://doi.org/10.1016/j.autcon.2014.05.013

Jayant, A., Gupta, P., Garg, S. K., \& Khan, M. (2014). TOPSIS-AHP based approach for selection of reverse logistics service provider: a case study of mobile phone industry. Procedia Engineering, 97, 2147-2156. https://doi.org/10.1016/j.proeng.2014.12.458

Kohler, H. P., Billari, F. C., \& Ortega, J. A. (2002). The emergence of lowest-low fertility in Europe during the 1990s. Population and Development Review, 28(4), 641-680.

https://doi.org/10.1111/j.1728-4457.2002.00641.x

Lai, M. M., Lein, S. Y., Lau, S. H., \& Lai, M. L. (2016). Modeling age-friendly environment, active aging, and social connectedness in an emerging Asian economy. Journal of Aging Research, 2016, 2052380. https://doi.org/10.1155/2016/2052380

Li, S. Z. (2013). Planning and design criteria for day care centers for the elderly (Commissioned by the Architectural Research Institute of the Ministry of the Interior). http://www.abri.gov. tw/tw/research/dl/1735/1 (in Chinese)

Lin, C. C., Wang, W. C., \& Yu, W. D. (2008a). Improving AHP for construction with an adaptive AHP approach $\left(\mathrm{A}^{3}\right)$. Automation in Construction, 17(2), 180-187.

https://doi.org/10.1016/j.autcon.2007.03.004
Lin, M. C., Wang, W. C., Chen, M. S., \& Chang, C. A. (2008b). Using AHP and TOPSIS approaches in customer-driven product design process. Computers in Industry, 59(1), 17-31. https://doi.org/10.1016/j.compind.2007.05.013

Lin, Y. C., \& Lin, T. L. (2015).The establishment of reusing vacant school space for senior care center assessment mechanism and the comparison of the importance of factors. Taoyuan Journal of Innovation, 35, 399-428 (in Chinese).

Malili, A. A., Owens, G., \& Bruce, D. (2012). Combining AHP and TOPSIS approaches to support site selection for a lead pollution study. Paper presented at the $2^{\text {nd }}$ International Conference on Environmental and Agriculture Engineering, IACSIT Press, Singapore.

Markham, J. P., \& Gilderbloom, J. I. (1998). Housing quality among the elderly: a decade of changes. International Journal of Aging and Human Development, 46(1), 71-90. https://doi.org/10.2190/A6EQ-FY4C-F4CF-18G9

Ministry of Health and Welfare. (2013). 2010 national long-term care needs survey. The Ministry of Health and Welfare. https:// www.sfaa.gov.tw/SFAA/Pages/ashx/File.ashx?FilePath= /File/ Attach/2101/File_2598.pdf (in Chinese)

Mitchell, L., Burton, E., \& Raman, S. (2003). Making the outside world dementia-friendly: design issues and considerations. Environment and Planning B: Planning and Design, 30(4), 605-632. https://doi.org/10.1068/b29100

Mitchell, L., Burton, E., \& Raman, S. (2004). Neighbourhoods for life - a checklist of recommendations for designing dementiafriendly outdoor environments. Oxford Centre for Sustainable Development and the Housing Corporation.

National Development Council. (2012). Taiwan population estimate 2012-2060. National Development Council. http://iknow.stpi.narl.org.tw/Post/Files/policy/2012/policy_12_037_2.pdf (in Chinese)

National Development Council. (2018a). Aging time. National Development Council. https://www.ndc.gov.tw/Content_List. aspx?n=695E69E28C6AC7F3 (in Chinese)

National Development Council. (2018b). Taiwan population estimate 2018-2065. National Development Council. https:// ws.ndc.gov.tw/Download.ashx?u=LzAwMS9hZG1pbmlzdHJ hdG9yLzEwL3JlbGZpbGUvMC8yODY3L2MyNTIzNTk1LT JiZTMtNDI0Yy05NWQ2LWIxMDk4YTA1N2NhNi5wZGY \%3D\&n=MTA35bm054mI5Lq65Y\%2Bj5o6o5Lyw5aCx5ZG KdjkgLWZpbmFsLnBkZg\%3D\%3D\&icon=..pdf (in Chinese)

Opricovic, S., \& Tzeng, G. H. (2004). Compromise solution by MCDM methods: a comparative analysis of VIKOR and TOPSIS. European Journal of Operational Research, 156(2), 445-455. https://doi.org/10.1016/S0377-2217(03)00020-1

Rajak, M., \& Shaw, K. (2019). Evaluation and selection of mobile health (mHealth) applications using AHP and fuzzy TOPSIS. Technology in Society, 59, 101186.

https://doi.org/10.1016/j.techsoc.2019.101186

Saaty, T. L. (1990). How to make a decision: the analytic hierarchy process. European Journal of Operational Research, 48(1), 9-26. https://doi.org/10.1016/0377-2217(90)90057-I

Saaty, T. L. (2003). Decision-making with the AHP: why is the principal eigenvector necessary. European Journal of Operational Research, 145(1), 85-91.

https://doi.org/10.1016/S0377-2217(02)00227-8

Shao, A. J. (2010). Analysis plan of the connotation, cost and adjustment mechanism of long-term care service in Taiwan (Commissioned research report by the Ministry of the Interior). https://www.sfaa.gov.tw/SFAA/Pages/ashx/File. ashx?FilePath= /File/Attach/346/File_647.doc (in Chinese)

Sumukadas, D., Witham, M., Struthers, A., \& McMurdo, M. (2009). Day length and weather conditions profoundly affect 
physical activity levels in older functionally impaired people. Journal of Epidemiology and Community Health, 63(4), 305309. https://doi.org/10.1136/jech.2008.080838

The Executive Yuan. (2018). Important policy. Long-term care services 2.0, more peace of mind. https://www.ey.gov.tw/ Page/5A8A0CB5B41DA11E/dd4675bb-b78d-4bd8-8be5e3d6a6558d8d (in Chinese).

World Health Organization. (2001). International classification of functioning, disability, and health. World Health Organization. https://www.who.int/classifications/icf/en/
World Health Organization. (2007). Global age-friendly cities: a guide. WHO, Geneva, Switzerland.

Wu, W. C., Lien, H. M., \& Lin, C. C. (2004). The impact of housing ownership and quality on the health status of the elderly in Taiwan. Journal of City and Planning, 31(4), 313-324.

$\mathrm{Yu}, \mathrm{H}$. J. (2013). Study on the living environment development of ageing society (Research project report). Architecture and Building Research Institute, Ministry of the Interior. https:// www.abri.gov.tw/tw/research/show/2672/p/print (in Chinese)

\section{Appendix}

\begin{tabular}{|c|c|c|c|c|c|c|}
\hline & A project & B project & C project & $D$ project & E project & F project \\
\hline Photos (current condition) & 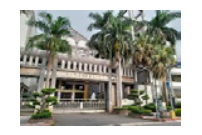 & min & 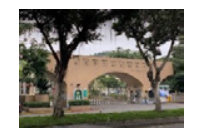 & 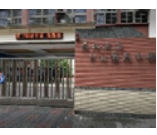 & I) & 211 \\
\hline Location & Beitou District & Shilin District & Neihu District & $\begin{array}{l}\text { Songshan } \\
\text { District }\end{array}$ & $\begin{array}{c}\text { Nangang } \\
\text { District }\end{array}$ & $\begin{array}{l}\text { Wenshan } \\
\text { District }\end{array}$ \\
\hline Established year & 1992 & 1979 & 1983 & 1977 & 1967 & 1975 \\
\hline Number of classes & 11 & 10 & 42 & 27 & 42 & 12 \\
\hline Student number & 312 & 167 & 1362 & 809 & 1397 & 328 \\
\hline Number of teachers & 31 & 34 & 54 & 62 & 88 & 31 \\
\hline Campus space available $\left(\mathrm{m}^{2}\right)$ & 10.355 & 25.562 & 40.559 & 17.338 & 26.222 & 15.647 \\
\hline Available classroom & 9 & 10 & 25 & 24 & 40 & 14 \\
\hline Green space area $\left(\mathrm{m}^{2}\right)$ & 3.020 & 5.232 & 6.000 & 4.160 & 7.550 & 4.680 \\
\hline
\end{tabular}

\begin{tabular}{|c|c|c|c|c|c|c|}
\hline \multirow[b]{2}{*}{ Photos (current condition) } & $G$ project & H project & I project & J project & $K$ project & $L$ project \\
\hline & 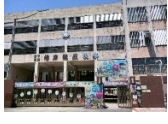 & & 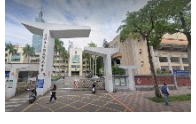 & (4) & & 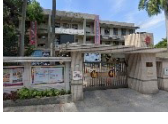 \\
\hline Location & $\begin{array}{l}\text { Wanhua } \\
\text { District }\end{array}$ & $\begin{array}{l}\text { Zhongzheng } \\
\text { District }\end{array}$ & Xinyi District & Daan District & $\begin{array}{c}\text { Zhongshan } \\
\text { Area }\end{array}$ & $\begin{array}{l}\text { Datong } \\
\text { District }\end{array}$ \\
\hline Established year & 1967 & 1968 & 1985 & 2004 & 2005 & 1969 \\
\hline Number of classes & 19 & 24 & 57 & 48 & 24 & 9 \\
\hline Student number & 395 & 798 & 1545 & 1750 & 612 & 186 \\
\hline Number of teachers & 42 & 55 & 87 & 119 & 31 & 30 \\
\hline Campus space available $\left(\mathrm{m}^{2}\right)$ & 16.605 & 20.160 & 33.923 & 34.613 & 24.218 & 24.834 \\
\hline Available classroom & 13 & 23 & 44 & 48 & 10 & 9 \\
\hline Green space area $\left(\mathrm{m}^{2}\right)$ & 3.560 & 5.000 & 3.600 & 3.330 & 5.090 & 1.600 \\
\hline
\end{tabular}

